\title{
Use of computers and applications by senior executives
}

\author{
Josep Lluís Cano Giner \\ ESADE Business School (SPAIN) \\ joseplluis.cano@,esade.edu
}

Received March 2011

Accepted June 2011

\section{Abstract:}

Purpose: Analyze the relationship between the senior executive and ICT use.

Design/methodology/approach: Empirical research through which we propose a framework to establish the main factors that might lead to an increase in ICT use by senior executives.

Findings: The main contribution of the present study is the creation of the list of factors that affect the use of computers and applications by senior executives and a smaller group of categories.

Research limitations/implications: A limitation of this research is that it should be confirmed by means of quantitative research that would allow us to test the validity of the proposed framework, and also to ascertain the relative importance of each factor.

Practical implications: Thus reducing the number of factors and forming a smaller group of categories that can facilitate research.

Originality/value: The list of factors that affect the use of computers and applications by senior executives and the smaller group of categories.

Keywords: senior executive, users, information and communication technologies, executive information system 


\section{Introduction}

The information and communication technologies (ICTs) have increased the productivity of various groups within organisations, but one of the groups that has adopted ICTs least is that of senior executives. The aim of the present paper is to analyse the factors that affect the use of ICTs by senior executives, gathering them together within a reference framework that will enable us to take them into account when implementing systems intended for this group. If senior executives adopted ICTs more widely, they would increase their productivity.

The beginnings of the relationship between ICTs, executives and decision making can be traced back to the times of the first computers. Over the years several arguments have been put forward to explain the lack of computer use among executives, including: their poor keyboard skills, their lack of training and experience in computer use, and even concern about their status, as they felt that using a computer was not part of their job, along with a set of other reasons related to the alternative between the flexibility or simplicity of systems, that is, if systems were inflexible or over-simple they added no value. But there are other cases in which executives overcome these reasons, for example that of LockheedGeorgia (Houdeshel \& Watson, 1987). In the mid 1950s, it was the opinion of most scientists that computers would have a notable impact on scientific calculation (e.g., in astronomy and the military sphere). A few (including Russell Ackoff, John Diebold and J.W. Forrester) agreed that computers would, in the immediate future, revolutionise the work of executives in policies, strategy and decision making (Drucker, 1998). The possibility that computers and applications would affect the way executives work was already anticipated. Although computers existed before this date, 1965 marked an unprecedented change when IBM presented their System/360 family. At that moment, scientists began to ask themselves how computers might help humans to improve decision making. Collaborations between scientists at the Carnegie Institution, together with Marvin Minsky of the Massachusetts Institute of Technology and John McCarthy of Stanford University, developed the first cognitive computer models, which were the embryo of artificial intelligence (Buchanan \& O'Connell, 2006). 
The paper starts with a description of the methodology and a literature review to establish a definition of the senior executive. We then go on to examine the various research projects that have been carried out on the use of applications or computers by senior executives, and conclude with a proposal of what we consider to be the key factors in the development of applications intended for senior executives.

As we will see presently, the key factors are related to the senior executives themselves, the system or application, and the project.

\section{Methodology}

The paper starts with a review of the existing literature, in two parts: one related to how we define a senior executive, and the other to analyse the relationship between the senior executive and ICT use. In the first part a definition is adopted, on the basis of a single previous literature review, as it is not the purpose of this paper to examine senior executives as such but rather their relationship with ICTs. In this second part we analyse, in chronological order, the contributions of various authors, separating out the reasons against the use of computers and applications by executives; the reasons in favour of the use of computers and applications by executives; and the factors to increase the use of computers and their applications. After analysing the literature, we group the factors according to whether they are related to the senior executives, the system or application, the project, or other reasons; and we propose a framework of factors that should be taken into account to increase ICT use by senior executives.

\section{Senior executives}

In the present paper we will adopt the definition of the senior executive proposed by Seeley and Targett (1997): "an executive who is concerned with the strategic direction of their organization's business". Furthermore, the senior executive: "is in a position to influence significantly the strategic decision-making processes for their function and/or the organization; has substancial control and authority over how resources are deployed; is in a position to influence the strategic direction of the Business of their function/organization; may have other senior managers reporting to him or her". 


\section{Studies on the use of computers and applications by senior executives}

There are several studies in the literature that analyse the use made of computers and applications by senior executives. In this section we will describe them.

One of the first studies was conducted by Brady (1967), and addressed the issue of whether computers had changed the method, the form or the content of executives' decision making. He concluded his study stating that computers had had no impact on how executives made decisions. In the same study he indicated that executives were not using computers due to:

- Lack of understanding (or training) of how computers can be used for decision making by executives

- A defensive attitude on the part of some executives regarding the threat posed by computers to their decision-making functions and their prerogatives to exert their "opinion"

- Lack of development of applications intended for decision making

- Indecision on the part of executives in formally identifying the decisionmaking criteria they wanted to use

- Executives' tendency to wait for other firms to invest and take the risk of pioneering the use of new computer applications

Brady (1967) forecast that significant advances in the impact of computers would be achieved simply as a consequence of the passing of time and staff movements, although he recommended speeding up changes by developing and training both middle and senior executives. In the conclusion of his study he predicted that by the mid 1970s computers would cause changes in a large number of aspects related to executive decision making.

One of the key papers dealing with computer use by executives is "The CEO goes on-line" (Rockart \& Treacy, 1982). In it, the authors show how CEOs increasingly access and use information from computers on a regular basis. They describe how four senior executives use computers, specifically with EIS applications (Executive Information Systems), which offer them analytical tools in their search for greater insight into their companies and sectors, the possibility of personalising them to 
meet each executive's information needs, and the possibility of implementing them by starting with small projects that can grow gradually. EISs are intended to help executives to use information more effectively. The authors conclude their paper with the following statement:

"Not all senior managers, of course, will find and EIS system to their taste, but enough user-friendly technology now exists to accommodate the needs of those who wish to master a more data-intensive approach to their jobs".

PC use by executives was subsequently analysed by Mawhinney and Lederer (1990), employing a model formed by four groups of variables: manager's attributes in the organisation (level, span of control, type of work, control of the system, contribution to job performance), personal attributes (age, sex, level of training, typing skills, competence in using the system), system attributes (ease of learning, ease of use, accessibility, response time, suitability), and process attributes (participation in the acquisition, satisfaction with the system, training in its use, technical support). The authors analyse how these variables affected PC use by the executives, discovering that none of the groups of variables seemed to dominate the model and that the two items with the strongest correlation with reported use time were (1) the system's contribution to job performance and (2) the managers' level of competence with the system.

Managers are reluctant to spend extra time learning other applications when they can do what they want on a spreadsheet, even if this is not the most efficient way of doing it, according to Seeley and Targett (1997). The authors report on several studies analysing senior executives as computer users. In the conclusions of their paper they state that senior executives use computers more extensively than before, that they use a larger number of applications more competently than they used to, and that the number of applications they use can be related to age (younger executives use a wider range of applications).

In his article "The next information revolution" (1998), Drucker investigates the meaning and the purpose of information. The author states that senior executives did not use new technologies because these technologies did not provide them with the information they needed for their work; likewise, he argues that the accounting systems at their disposal do not help them in decision making. Another aspect he 
highlights is that senior executives have a degenerative tendency, especially in the big corporations: to focus inwards (on costs and results) rather than outwards (on opportunities, changes and threats). Consequently he predicted a trend over the following 10 to 15 years towards collecting outside information. One of the factors that can cause a change in the trend is the stronger training in technologies that he forecasts senior executives will have in the future. Another issue that is addressed is whether system employees and chiefs are prepared to attend to senior executives about ICTs in the medium they require.

In their study on senior executives' personal use of computers, Seeley and Targett (1999) conclude that it is related to the dynamic and complex iteration between both internal factors, such as executives' perception of their role as managers, modus operandi and personality, and certain external factors, such as system infrastructures, the nature of the task and organisational culture.

Poon and Wagner (2001) revise the Critical Success Factors model (Rockart \& DeLong, 1988) to apply it to information systems for executives, confirming the applicability of Rockart and DeLong's eight original factors plus two additional ones. Nevertheless, they consider that, out of all the success factors, we will achieve success if we manage just three of them: support at both executive and operational levels; resources; and linking the system to the business objectives.

According to Pijpers, Bemelmans, Heemstra and van Montfort (2001), the perception of fun/enjoyment that senior executives may have when using an information system is an external variable that influences beliefs about, attitude to and use of systems.

Xu and Kaye (2002) analyse the support needs of executives, concluding that they need support from information specialists rather than technology specialists, the function of the former being to scan external information in the outside world, turn it into meaningful information and make it easily accessible to managers so that they can use it. Consequently, when EISs are designed and implemented, we must train the executives not only to use the system but also about what information they will find, systematically updated, analysed and formatted by information specialists before the executives use the system. These specialists must therefore be familiar with the culture of the executives; they must exploit and obtain the 
vision of the executives and the knowledge to judge and interpret the information and make explicit that which must be shared among information specialists.

We must take into account the differences between expert and novice executive computer users, as shown by Hung (2003). Executives' skills affect system use; expert users require less time to reach a solution and view more screens when performing analytical tasks, whereas novices view more screens when performing more intuitive ones, and executives feel more useful when they use more powerful systems. Furthermore, expert users consider intuitive systems to be more useful than analytical ones, whereas the difference is not significant for novices.

Senior executives are not benefiting from the use of technologies (Seyal \& Pijpers, 2004). Lack of commitment to the use of ICTs and their applications can be regarded as a threat to competitiveness. According to the authors there are several reasons accounting for impediments to ICT use: (1) senior executives have little time to play around with new technologies, (2) senior executives are reluctant to use the technology due to PC anxiety, and (3) senior executives lack skill and proficiency in ICT use, and moreover lack support staff to answer their queries. Some senior executives argue that they see no connection what ICTs do and their task as senior executives. The reaction to ICTs is even worse if they took no ITrelated course during their college years.

Internationalisation has created the need to assess whether senior executives make strategic decisions differently depending on their origin. Martinsons and Davison (2007) analyse the differences among American, Japanese and Chinese executives, between whom they establish different decision styles; hence information technologies must be adapted to the different styles of their users.

\section{$5 \quad$ Analysis and results}

On the basis of the above literature review, we present the various studies in Table 1, separating: reasons against the use of computers and applications; reasons in favour of the use of computers and applications; and key factors to increase the use of computers and applications by senior executives. For each factor we indicate in parentheses whether they are related to: Senior Executives (SE), the System $(\mathrm{S})$, the Project $(\mathrm{P})$, or Other factors $(\mathrm{O})$. This classification will then enable us to sort and aggregate them. For most factors their relationship with $S E, S, P$, and $O$ is 
clear, and when they can be related to more than one factor the most relevant is chosen. It is not necessary to state the justification for each factor, but by way of example, one of the reasons against computer use for Brady (1967) is "Lack of understanding of computer use", as can be seen in Table 1, and this has been related to Senior Executives, as it clearly depends on them. In turn, "Link system to business objectives", for example, as proposed by Poon and Wagner (2001), has been related to the Project, as it depends on the definition of each particular project, and so on for the rest of the factors.

\begin{tabular}{|c|c|c|c|}
\hline Author & Reasons against use & $\begin{array}{c}\text { Reasons in favour of } \\
\text { use }\end{array}$ & Factors to increase use \\
\hline Brady (1967) & $\begin{array}{l}\text { Lack of understanding } \\
\text { of computer use. (SE) } \\
\text { A defensive attitude. } \\
\text { (SE) } \\
\text { Lack of development of } \\
\text { applications. (S) } \\
\text { Indecision on the part of } \\
\text { executives in formally } \\
\text { identifying the decision- } \\
\text { making criteria they } \\
\text { wanted to use. (SE) } \\
\text { Executives' tendency to } \\
\text { wait for other firms to } \\
\text { invest and take the risk } \\
\text { of being pioneers. (SE) }\end{array}$ & & $\begin{array}{l}\text { Stronger training in } \\
\text { computer use. (SE) } \\
\text { Passing of time. (O) } \\
\text { Management changes due } \\
\text { to staff movements. (O) }\end{array}$ \\
\hline $\begin{array}{l}\text { Rockart and } \\
\text { Treacy (1982) }\end{array}$ & & $\begin{array}{l}\text { Availability of } \\
\text { applications designed for } \\
\text { executives' tasks. (S) } \\
\text { Personalisation of } \\
\text { applications. (S) } \\
\text { Incremental projects. (P) }\end{array}$ & \\
\hline $\begin{array}{l}\text { Mawhinney and } \\
\text { Lederer (1990) }\end{array}$ & & $\begin{array}{l}\text { Contribution to job } \\
\text { performance. (SE) } \\
\text { Level of competence with } \\
\text { the system. (SE) }\end{array}$ & \\
\hline $\begin{array}{l}\text { Seeley and } \\
\text { Targett (1997) }\end{array}$ & $\begin{array}{l}\text { Reluctance to spend } \\
\text { extra time learning } \\
\text { applications other than } \\
\text { spreadsheets. (SE) } \\
\text { Older executives use a } \\
\text { narrower range of } \\
\text { applications. (SE) }\end{array}$ & & \\
\hline Drucker (1998) & $\begin{array}{l}\text { System did not provide } \\
\text { them with the necessary } \\
\text { information. }(P)\end{array}$ & & $\begin{array}{l}\text { Need for systems to collect } \\
\text { more external information. } \\
\text { (P) } \\
\text { Stronger ICT training for } \\
\text { executives. (SE) } \\
\text { System chiefs capable of } \\
\text { attending to executives' } \\
\text { demands. (P) }\end{array}$ \\
\hline $\begin{array}{l}\text { Seeley and } \\
\text { Targett (1999) }\end{array}$ & & & $\begin{array}{l}\text { Executives' perception of } \\
\text { their role as managers. } \\
\text { (SE) } \\
\text { Modus operandi. (SE) } \\
\text { Personality. (SE) } \\
\text { System infrastructures. (P) } \\
\text { Nature of the task. (SE) } \\
\text { Organisational culture. (O) }\end{array}$ \\
\hline
\end{tabular}




\begin{tabular}{|c|c|c|c|}
\hline $\begin{array}{l}\text { Poon and } \\
\text { Wagner (2001) }\end{array}$ & & & $\begin{array}{l}\text { Support at both executive } \\
\text { and operational levels. (P) } \\
\text { Available resources. (P) } \\
\text { Linking the system to the } \\
\text { business objectives. (P) }\end{array}$ \\
\hline $\begin{array}{l}\text { Pijpers, } \\
\text { Bemelmans, } \\
\text { Heemstra and } \\
\text { van Montfort } \\
\text { (2001) }\end{array}$ & & $\begin{array}{l}\text { Perception of fun or } \\
\text { enjoyment in ICT use. } \\
\text { (SE) }\end{array}$ & \\
\hline $\begin{array}{l}\text { Xu and Kaye } \\
(2002)\end{array}$ & & & $\begin{array}{l}\text { Support from information } \\
\text { specialists. (P) }\end{array}$ \\
\hline Hung (2003) & & & $\begin{array}{l}\text { Need to adapt systems to } \\
\text { executives' experience. (S) }\end{array}$ \\
\hline $\begin{array}{l}\text { Seyal and } \\
\text { Pijpers (2004) }\end{array}$ & $\begin{array}{l}\text { Little time to play } \\
\text { around with new } \\
\text { technologies. (SE) } \\
\text { Reluctance to use the } \\
\text { technology due to PC } \\
\text { anxiety. (SE) } \\
\text { Lack of skill and } \\
\text { dexterity in ICT use. } \\
\text { (SE) } \\
\text { Lack of support staff to } \\
\text { answer their queries. } \\
\text { (P) } \\
\text { No connection seen } \\
\text { between what ICTs do } \\
\text { and their task as } \\
\text { executives. (SE) }\end{array}$ & & \\
\hline $\begin{array}{l}\text { Martinsons and } \\
\text { Davison (2007) }\end{array}$ & & & $\begin{array}{l}\text { Adapt to the different } \\
\text { styles of their users. (S) }\end{array}$ \\
\hline
\end{tabular}

Table 1. "Summary of reasons against, reasons in favour of, and factors to increase the use of computers and applications by senior executives".

The 37 reasons cited by various authors and studies and presented in Table 1 were each allocated to one of the following categories: Senior Executives, System, Project, or Others. Subsequently, with the object of reducing the number of factors, whenever possible they were grouped together taking into account those that are alike and had been cited in more than one of the studies involved. In the event of the factors being insufficiently alike they were maintained in different groups. Table 2 shows all the groups and each factor allocated within the new classification, which includes all the contributions of the various studies. For example, the factors grouped together owing to their relationship with the Project as "availability of resources" are: lack of support staff to answer their queries, support from information specialists, system chiefs capable of attending to executives' demands, available resources, and system infrastructures; each of these factors is clearly related to the availability of resources (both economic and personal) in a project. However, the factors grouped together under "resource availability" are not related to other project groups, i.e., they are not related to: 
"support from management", "incremental project" or "alignment". In the analysis we have taken into account each factor and its possible relationship with the rest. Those that were not related to any others have been kept apart to form a group of their own. This is the case, for example, with the tendency of executives to wait for other firms to invest and take the risk of being the first; this factor is not related to any of the other 36 .

\begin{tabular}{|c|c|c|}
\hline Relationship & Groups of factors & Factors \\
\hline \multirow{9}{*}{$\begin{array}{l}\text { Senior } \\
\text { Executives }\end{array}$} & ICT training & $\begin{array}{l}\text { Lack of understanding of computer use. } \\
\text { Stronger training in computer use. } \\
\text { Reluctance to spend extra time learning applications } \\
\text { other than spreadsheets. } \\
\text { Stronger ICT training for executives. } \\
\text { Little time to play around with new technologies. }\end{array}$ \\
\hline & $\begin{array}{l}\text { Competence in using the } \\
\text { system }\end{array}$ & $\begin{array}{l}\text { Level of competence with the system. } \\
\text { Lack of skill and dexterity in ICT use. }\end{array}$ \\
\hline & o & $\begin{array}{l}\text { Older executives use a narrower range of } \\
\text { applications. }\end{array}$ \\
\hline & Personality & Personality. \\
\hline & Modus operandi & Modus operandi. \\
\hline & Attitude to ICTs & $\begin{array}{l}\text { Reluctance to use the technology due to PC anxiety. } \\
\text { Perception of fun or enjoyment in ICT use. } \\
\text { A defensive attitude. } \\
\text { Executives' perception of their role as managers. }\end{array}$ \\
\hline & $\begin{array}{l}\text { Ability to identify decision- } \\
\text { making criteria }\end{array}$ & $\begin{array}{l}\text { Indecision on the part of executives in formally } \\
\text { identifying the decision-making criteria they wanted } \\
\text { to use. }\end{array}$ \\
\hline & Contribution of ICTS & $\begin{array}{l}\text { Nature of the task. } \\
\text { No connection seen between what ICTs do and their } \\
\text { task as executives. } \\
\text { Contribution to job performance. }\end{array}$ \\
\hline & $\begin{array}{l}\text { Risk aversion against } \\
\text { investing in ICTs }\end{array}$ & $\begin{array}{l}\text { Executives' tendency to wait for other firms to invest } \\
\text { and take the risk of being pioneers. }\end{array}$ \\
\hline \multirow[t]{2}{*}{ System } & Functionality of the system & $\begin{array}{l}\text { Personalisation of applications. } \\
\text { Adapt to the different styles of their users. } \\
\text { Need to adapt systems to executives' experience. } \\
\text { Lack of development of applications. }\end{array}$ \\
\hline & Specificity of the system & $\begin{array}{l}\text { Availability of applications designed for executives' } \\
\text { tasks. }\end{array}$ \\
\hline \multirow{4}{*}{ Project } & Support from management & Support at both executive and operational levels. \\
\hline & Resource availability & $\begin{array}{l}\text { Lack of support staff to answer their queries. } \\
\text { Support from information specialists. } \\
\text { System chiefs capable of attending to executives' } \\
\text { demands. } \\
\text { Available resources. } \\
\text { System infrastructures. }\end{array}$ \\
\hline & Incremental project & Incremental project. \\
\hline & Alignment & $\begin{array}{l}\text { Linking the system to the business objectives. } \\
\text { System did not provide them with the necessary } \\
\text { information. } \\
\text { Need for systems to collect more external } \\
\text { information. }\end{array}$ \\
\hline Others & Other factors & $\begin{array}{l}\text { Passing of time. } \\
\text { Organisational culture. } \\
\text { Management changes due to staff movements. }\end{array}$ \\
\hline
\end{tabular}

Table 2. "Relationship of factors with: Senior Executives, System, Project and Others". 
Those factors that are not directly related to Senior Executives, the System or the Project have been grouped together in the category Others, and they have not been merged owing to their diversity. This is one of the limitations of the study.

\section{Conclusions, implications and limitations}

In this paper we report the results of empirical research through which we propose a framework to establish the main factors that might lead to an increase in ICT use by senior executives. We group these factors together into three categories: those related to the senior executive, to the system, and to the project. In the literature review, it is shown that none of the existing studies take the totality of the factors into account simultaneously. Thus the main contribution of the present study is the creation of the list of factors that affect the use of computers and applications by senior executives.

The creation of this list of factors has a practical research implication, namely to provide researchers with a common list of factors that they can use in their work (Cano Giner, Fernandez, Diaz Boladera, 2009). On the basis of the literature review, we represent the information in Table 1, making the various factors easier to understand and indicating the relationship each of them has with the Senior Executives, the System, the Project and Others. We then group the factors together within each of these categories, thus reducing the number of factors and forming a smaller group of categories that can facilitate research, as shown in Table 2. As the intermediate steps are displayed, researchers can check for themselves the appropriateness of the groupings.

A limitation of this research is that it should be confirmed by means of quantitative research that would allow us to test the validity of the proposed framework, and also to ascertain the relative importance of each factor.

\section{References}

Brady, R. H. (1967). Computers in top-level decision making. Harvard Business Review, 45(4): 67-76.

Buchanan, L., \& O'Connell, A. (2006). A brief history of decision making. Harvard Business Review, 84(1): 32-41. 
Cano Giner, J., Fernandez, V., \& Díaz Boladeras, M. (2009). Framework for the analysis of executive information systems based on the perceived usefulness and the perceived ease of use. Intangible Capital, 5(4): 370-386

doi: 10.3926/ic.2009.v5n4.p370-386

Drucker, P.F. (1998). The next information revolution. Forbes ASAP, August 24, 4758.

Houdeshel, G., \& Watson, H. J. (1987). The Management Information and Decision Support (MIDS) system at Lockheed-Georgia. MIS Quarterly, 11(1): 127-140. doi: $10.2307 / 248834$

Hung, S. Y. (2003). Expert versus novice use of the executive support systems: An empirical study. Information \& Management, 40(3): 177-189.

doi: 10.1016/S0378-7206(02)00003-4

Martinsons, M. G., \& Davison, R. M. (2007). Strategic decision making and support systems: Comparing American, Japanese and Chinese management. Decision Support Systems, 43(1): 284-300.

doi: 10.1016/j.dss. 2006.10.005

Mawhinney, C. H., \& Lederer, A. L. (1990). A study of personal-computer utilization by managers. Information \& Management, 18(5): 243-253.

doi: 10.1016/0378-7206(90)90026-E

Pijpers, G. G. M., Bemelmans, T. M. A., Heemstra, F. J., \& van Montfort, K. A. G. M. (2001). Senior executives' use of information technology. Information and Software Technology, 43(15): 959-971.

doi: 10.1016/S0950-5849(01)00197-5

Poon, P., \& Wagner, C. (2001). Critical success factors revisited: Success and failure cases of information systems for senior executives. Decision Support Systems, 30(4): 393-418.

doi: 10.1016/S0167-9236(00)00069-5

Rockart, J.F., \& DeLong, D.W. (1988). Executive Support Systems: The Emergence of Top Management Computer Use. Illinois: Dow J ones-I Irwin. 
Rockart, J. F., \& Treacy, M. E. (1982). The CEO goes on-line. Harvard Business Review, 60(1): 82-88.

Seeley, M., \& Targett, D. (1999). Patterns of senior executives' personal use of computers. Information \& Management, 35(6): 315-330.

doi: 10.1016/S0378-7206(99)00002-6

Seeley, M. E., \& Targett, D. (1997). A senior executive end-user framework. Information Systems J ournal, 7(4): 289-308.

doi:10.1046/j.1365-2575.1997.00019.x

Seyal, A. H., \& Pijpers, G. G. M. (2004). Senior government executives' use of the internet: A Bruneian scenario. Behaviour \& Information Technology, 23(3): 197210.

Xu, X. Z. M., \& Kaye, G. R. (2002). Knowledge workers for information support: Executives' perceptions and problems. Information Systems Management, 19(1): 81-88.

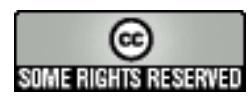

Article's contents are provided on a Attribution-Non Commercial 3.0 Creative commons license. Readers are allowed to copy, distribute and communicate article's contents, provided the author's and Journal of Industrial Engineering and Management's names are included. It must not be used for commercial purposes. To see the complete license contents, please visit http://creativecommons.org/licenses/by-nc/3.0/. 